\title{
Janika Päll
}

\section{MEREMOTIIV ÜLEVA PILDIKEELES: PAARI NÄITEGA EESTI LUULEST}

Artikli eesmärk on esmalt näidata, milliste kujutluspiltidega seostub üleva teooria alusepanija, vanakreeka kirjandusteoreetik Longinuse jaoks ïlev looming, seejärel näidatakse ära olulisemad vaheetapid üleva motiivistiku teel eesti luulesse. Edasi keskendub artikkel ülevuse taotlemisele seoses meremotiividega eesti luules (Kristjan Jaak Peterson ja Villem Ridala), paralleelidega muusikast ja maalikunstist. Artikli lõpp näitab ülevas stiilis ooditraditsiooni võimalikku mõju George Gordon Byroni luuletuse "Muusikale" tõlkele: üleva stiili taotlemisel on lähteteksti ülevasse registrisse kuuluvaid motiive pisut tugevdatud, et vältida registri madaldumist.

\section{ÜLEVA TEOORIA ANTIIKAJAL}

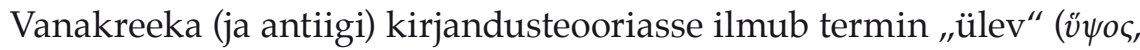
ld sublime) suhteliselt hilja võrreldes ülevaks peetud žanride - eepos, hümnid jumalaile - tekke- ja hiilgeajaga. Kreeka keeles kõrgust tähistav tüvi viitab liitsõna osisena suurejoonelisele kõnepruugile juba Homerose

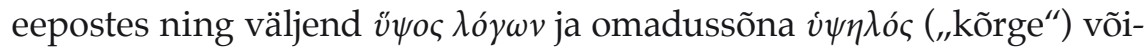
vad tähistada ülevat kõnestiili hellenismiajal, ${ }^{1}$ ent põhiteemana esineb „ülevus“ säilinud kirjandusteoreetilistes käsitlustes vaid nii-nimetatud Longinuse (või Dionysios Longinose või ka Pseudo-Longinuse) samanimelises traktaadis, mille tõenäoliseks loomisajaks on 1. sajandi algus $\mathrm{pKr}^{2}$ Longinus on poleemikas oma eelkäija, roomlase Caeciliuse trak-

DOI: http://dx.doi.org/10.12697/BJAH.2016.11.03

Käesolev artikkel on kirjutatud ETAG'i grant PUT 132 raames.

1 Vt Janika Päll, „Ülevuse anonüümne techne: Ps-Longinuse traktaat ülevusest“, Techne, toim. Mart Jaanson, Monika Kaldalu, Janika Päll (Tallinn: Scripta Musicalia, 2002), 59-60.

2 Lihtsuse huvides viitan autorile edaspidi kui Longinusele. Ülevaadet autorsuse ja dateerimise debatist ning argumentidest 1. sajandi pKr alguse kasuks: Casper de Jonge, „Dionysius and Longinus on the Sublime: Rhetoric and Religious Language“, American Journal of Philology, vol. 133, 2 (2012), 271-276, 292-296. 
taadiga $^{3}$ ja haakub hästi Augustuse-aegse debatiga Platonist lähtuva üleva mõiste üle, ${ }^{4}$ samas ei polemiseeri ta stiiliteooriaga üldiselt ega erista ülevat stiili teistest kõrgstiili iseloomustavatest terminitest, mida ta üleva sünonüümidena mitmel pool kasutab. ${ }^{5}$ Ülevuse mõiste koht Longinuse käsitluses on antiigi stiiliteooriat täiendav: kõrge-keskmisemadala stiili süsteemis ${ }^{6}$ käsitleb ta kõrgstiili kui „ülevat“, lähtudes selle erilisest mõjust (ülendamine, endast välja viimine) ja päritolust (jumalik inspiratsioon, loomupärane suurus). ${ }^{7}$ Ülevus avaldubki Longinuse jaoks eelkõige vastupandamatus ja tugevas mõjus:

1.3. Mu armsaim, kirjutades sulle, kunstide tundjale, ei ole mul peaaegu üldse tarvis pikka sissejuhatust, et ülevus on mingi kõne tipp ja väljapaistvus ning et just selle ja mitte millegi muu tõttu on suurimad poeedid ja kirjanikud tõusnud esikohale ning saanud igikestva kuulsuse. 1.4. Loomupärane suurus ju ei veena kuulajaid, vaid viib endast välja. ${ }^{8}$ Imestusväärne koos hämmastamisega on alati tugevam kui lihtsalt usutav ja meeldiv, sest usutav sõltub enamasti meist, imestusväärne aga paneb mängu oma võimu ja vastupandamatu jõu ning jääb kuulaja ees peale. Ja me näeme, et teemaleidmise oskus ning asjaolude reastamine ja korrastamine ilmnevad järk-järgult, mitte ühest ega paarist sõnast, vaid terve kõne ülevusest, ülevus aga, mida raken-

3 Caeciliuse traktaat ei ole säilinud. Longinus kritiseerib Caeciliust, kuna too ei ole välja toonud üleva saavutamise vahendeid, eriti emotsioone selle allikana (1.1, 8.1 ja 8.4) ning on olnud ülekohtuselt kriitiline Theopompose ja Platoni suhtes, keda Longinus eriliselt hindab (4.2 ja 32.8), pisut tuselt kriitiline Theopompose ja Platoni suhtes, keda Longinus eriliselt hindab (4.2 ja 32.8$)$, pisut
neutraalsem on ta Caeciliuse Timaiose-kriitika ja liigse metafoorikasutuse kriitika suhtes ( 4.2 ja neutraalsem on ta Caeciliuse
32.1). Vt ka järgnevat märkust. 32.1). Vt ka järgnevat märkust.
4 Vt de Jonge, „Dionysius and Longinus on the Sublime: Rhetoric and Religious Language“, 292296; Donald A. Russell, „Longinus revisited , Mnemosyne, vol. 34, 1-2 (1981), 72-86, passim; Platonis: James I. Porter, The Sublime in Antiquity (Cambridge: Cambridge University Press, 2016), 557-600.

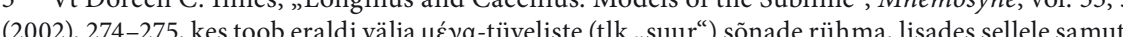

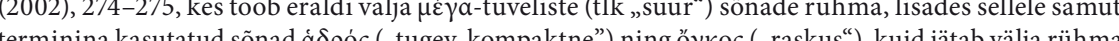

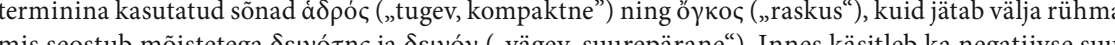

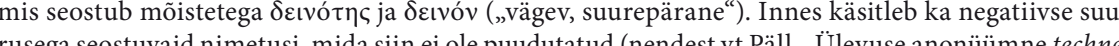
Fusega seostuvaid

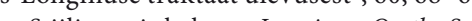

Stiiliteooria kohta vt Longinus. On the Sublime, ed. by Donald A. Russell (Oxford: Oxford University Press, 1964), xxxvi; Russell, „Longinus revisited”; Innes, „Longinus and Caecilius: Models of the Sublime , 275; de Jonge, „Dionysius and Longinus on the Sublime: Rhetoric and Religious Language “ $282-283$

Vt eelkõige Longinuse ptk 1.3, 14.12 ja 7.2

Selles lauses esinevaid mõistet $\mu \varepsilon \gamma a \lambda$ ó $\varphi v \varepsilon c$ tõlgitakse ja tôlgendatakse sageli kui „geniaalsust

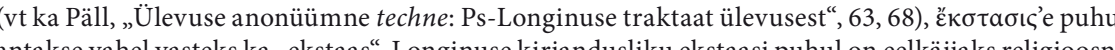
antakse vahel vasteks ka „ekstaas“. Longinuse kirjandusliku ekstaasi puhul on eelkäijaks religioosne Ekstase in der Literatur des 16. und 17. Jahrhunderts (Tübingen: Gunter Narr, 2001), 15-17, 25-30). datakse sobilikul hetkel, paiskab kõik asjad laiali otsekui välk ning teeb kohe nähtavaks kogu kõnemehe jõu. Ent ma arvan, mu sulnis Terentianus, et kõike sellesarnast võiksid sa ka ise oma kogemustest välja tuua.

Longinuse saatus on üllatav: tema analüüsid on kohati nii üksikasjalikud ja peened, et lõpuni kaasamõtlemiseks peaks lugeja valdama kreeka keelt ja kirjandust üsna põhjalikult, samuti võib ta moodsa kirjandusteooria või kognitiivsete uuringute jaoks näida aegununa (ligi 2000 aasta vanust analüüsimeetodit ei suuda ükski teadusbürokraatia aktsepteerida selle kestvast valiidsusest hoolimata). Ometi pole teda unustatud: koos Demetriose, Cicero, Halikarnassose Dionysiose ja Hermogenese stiilialaste käsitlustega on „Ülevusest“ võrreldamatu allikas selle kohta, kuidas tajuti ning analüüsiti antiikkirjandust selle loomise või loomisele lähedastel aegadel. Longinus pakub midagi ka teistele kunstidele peale kirjanduse, sest ta lähtub analoogiast loodusega. Nii on suur osa tema ideid loomeande allikate ja kunstiloomingu (ning looduse) tajumise kohta universaalsed. ${ }^{9}$

Kuigi kujutav kunst, ja eriti maalikunst oli Longinuse jaoks (nagu kreeklaste teoorias üldse) oma liigtäpse jäljendusviisi tõttu vähem oluline techne kui sõnakunst, ${ }^{10}$ nägid kreeklased kuulmise ning nägemise vahendatud emotsioonide mõjus hingele tugevat analoogiat. Sellele viitab 5. sajandil eKr sofist Gorgias „Helena ülistuskõnes“, mille järgi on kuulmise vahendatud kõne ja nägemise vahendatud vaatepilt võimelised võtma ära ja põhjustama erinevaid tundeid, sh valu, naudingut ja hirmu, loomulikult ka armastust: ${ }^{11}$

9 Ülevuse teema jõuline naasmine 21. sajandi alguse teooriasse viitab vajadusele nii üleva kogemise kui selle kaasaegse mõtestamise järgi. Vt Porter, The Sublime in Antiquity; Robert Doran, The Theor of the Sublime from Longinus to Kant (Cambridge: Cambridge University Press, 2015), 1-8; Augne Gedichte der Ekstase in der Literatur des 16. und 17. Jahrhunderts; Martin Fritz, Vom Erhabenen: der Traktat „Peri Hypsous" und seine ästhetisch-religiöse Renaissance im 18. Jahrhundert (Tübingen: Moh Siebeck, 2011); Maarten Delbeke, Jurgen Pieters, Caroline van Eck, Stijn Bussels, Translations of the Sublime: The Early Modern Reception and Dissemination of Longinus Peri Hypsousin Rhetoric, the Visual Arts, Architecture and the Theatre (Boston: Brill, 2012) ja paljud teised (sealhulgas eriti JeanFrançois Lyotard ist ule Immanuel Kanti lahtuvad käsitlused, millele eelnev huvilaine on seostatav

10 Vt Longinus, ptk 36.3: Sellele aga, kes kirjutas, et puudustega koloss ei ole parem Polykleitose Doryphorosest („Odakandja“), saab lisaks paljule muule öelda, et techne puhul imetletakse suurima täpsust, looduse teoste puhul aga suurust ... ja kui kujude puhul otsitakse sarnasust inimesega, siis kõn puhul seda, mis ületaks inimliku. Vt ka lisa.

$11 \operatorname{Vrd} 8$.... sest ta suudab ju hirmu löpetada ja muret ära võtta ja rõõmu valmistada ja kaastunnet äratada; 17. Mõned aga jäävad hirmsaid asju nähes ilma ka olemasolevast arukusest, sest hirm on nitviisi nende mõistuse kustutanud ja välja ajanud.... 19. Kui niisiis Helena silm, võlutuna Aleksandr Vorsokratiker, 6, hrsg. von Hermann Alexander Diels, Walther Kranz (Berlin: Weidmann, 1952), fr. 82B. 
9. kuulajaid haarab ülihirmutav kartus, pisararohke haledus ja valu põhjustav igatsus, nii et kui teiste teod või kehad kogevad õnne või õnnetust, siis kogeb ka hing kõne mõjul sama kui enda oma; ... 14. nõnda ka kõnedest mõni teeb haiget, mõni teeb rõomsaks, mõni toob hirmu, mõni teeb vapraks, mõni ent mürgitab ja nõiub kuulaja hinge mingi kurja veenmise abil. 17. Paljud aga langevad tühjade vaevade ja hirmsate haiguste ja ravimatute maaniate kütke, sest hirm on nähtud asjade kujutised nende meeltesse kirjutanud ... 18. Seevastu aga maalijad rõommustavad pilku, kui teevad paljude värvide ja kehade abil ühe keha ja kuju täiesti valmis.

Seda, kas lugeda Gorgiast üksikute säilinud fragmentide põhjal kognitiivsete uuringute ja taju (kui aisthēsis'e) teooriate alusepanijaks või mitte, pole siin võimalik otsustada, ${ }^{12}$ ent selge on, et ta pani tähele paralleele kuulmis- ja nägemismeele tugeva füüsilise mõju vahel ning ka nende sünesteesiat. ${ }^{13}$ Klassikaline näide kunsti ja kirjanduse võrdlusest (ut pictura poesis) on mitu sajandit hilisem, Horatiuse „Ars poeticas“, v. 361-365:14

Luuletus on nagu pilt: on sellist, mis ligi seistes

võimsamalt haarab, ja mõnd, mis siis kui kaugemal olla: armastab üks hämarust, tuleb vaadata valguses teisi,

millised kartma ei pea terav-uurivat kriitiku pilku,

üks kord meeldiv on too, kuid teine jääb meeldima kümnel.

Horatiuse poolt tähele pandud valguse roll seoses tajumisega huvitab ka Longinust, kes võrdleb kõnekujundite kasutamist (ja vajadust neid vahel peita) looduse ja maalikunstiga (17.3):

Sest peaaegu samuti nagu siis, kui hämaramad valgused kaovad, kui nende ümber hïlgab päikene, varjutab ka kõikjalt ülevalguv suurejoonelisus retoorika peensused. Midagi samasugust juhtub ka maalikunsti puhul: nimelt kui ühel

12 Vt Jean-Paul Reding, Les fondements philosophiques de la rhétorique chez les sophistes grecs et chez les sophistes chinois (Bern: Peter Lang, 1985). Kriitilist kunstidele suunatud teooria osas: Andrew Ford, The Origins of Criticism: Literary Culture and Poetic Theory in Classical Greece (Princeton, Oxford
Princeton University Press, 2002), 172-187. 2010, aastateks näib uurijate konsensus olevat jouudnud järeldusele, et Gorgiase puhul on tegemist latentse esteetikateooriaga, olgu siis tegemist kairos'e, illusiooni (apatē), logose või tunnete mõjuga.

13 Gorgias, Helena enkoomium, 13.... kôned ... panid uskumatu ja nähtamatu ilmuma arvamuse silmade ette. Vt ka Agis Marinis, ,Seeing Sounds: Synaesthesia in the Parodos of Seven against Thebes“,

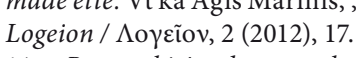

14 Rooma kirjanduse antoloogia, toim. Ain Kaalep ja Ülo Torpats, tlk Ülo Torpats (Tallinn: Eesti Raamat, 1971), 350. ja samal tasapinnal on kõrvuti kaks varjundit: valgus ja vari, püüab valgus enam pilku ning paistab väljapaistvamana ja ka palju lähedamal olevana. Ni on ka kõnede puhul: tunded ja ülev on meie hingedele palju lähedasemad mingi loomuliku suguluse ja hiilgavuse tõttu, ilmnedes alati enne kõnekujundeid ja varjutades nende kunstlikkuse ning hoides neid otsekui peidus.

Longinus tundis hästi Sappho luulet, kes kasutas kuu eredama valguse ja tähtede võrdlust oma loomingus mitmel pool, samuti polnud talle arvatavasti teadmata, et Cicero kasutas kõnekujundite kohta sõna lumina - retoorilised ja poeetilised figuurid pole seega lihtsalt tühipaljad kaunistused, vaid kõne „valgused“, mis annavad sellele hiilguse ja väljapaistvuse. ${ }^{15}$ Niisiis on ülevus nagu mingi eriliselt hiilgav kõnekujund, mis teised varju jätab.

Ent valgus, sära ja hiilgus on ka tähtsad motiivid, mis aitavad ülevust luua. Valgus esineb kõige alguses Longinuse poolt toodud üleva näites Genesisest: Jumal ütles: Saagu valgus, ... ja valgus sai (9.9), sellele järgneb näide Homerose „Iliasest", kus öisesse uttu mähkunud Aias palub valgust, et võiks vapralt lahingus surra ja elu lõpule vastu minna. ${ }^{16}$ Päikese valgus on elu sümbol ka vormellikes fraasides: „kuni elab ja näeb päi-

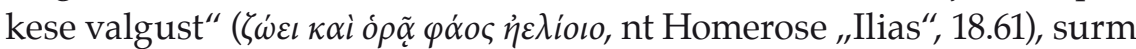
tähendab kreeklastele päevavalguse maha jätmist. Nii on Longinusel valguse motiiv seotud kõige äärmuslikumate momentidega: maailma loomise ning inimelu lõpuga. Valguse, eriti ereda ja hämarusega kontrastis oleva valguse olulisest rollist hoolimata võib ka hämarus ja nn „hämarad“ autorid, näiteks Pindaros, olla ülevad (peatükis 33.5). Pindarose uus populaarsus sai alguse renessansiajal, umbes siis, kui Longinuski taasavastati, ning ta on oma tihti väidetud raskepärasusest ja "tumedusest" hoolimata jäänud üleva luule sümboliks. ${ }^{17}$ Tema luules näeme

15 Ladina keeles võib kõnekujundeid metafoorselt tähistada nimisõna lumina („valgused“, nii selgitab Cicero dialoogi „Brutus“ 275 paragrahvi Martin Steinrück, vt Antike Formen. Materialien zur Geschichte von Katalog, Mythos und Dialog (Amsterdam: Hakkert, 2013), 50, märkus 107). 16 Mõlema ühendamisest Longinusel, vt de Jonge, „Dionysius and Longinus on the Sublime 16 Mõlema ühendamisest Longinusel, vt de Jonge, „Dionysius and Longinus on the Sublime: Schatten bei Pseudo-Longin", Alvarium. Festschrift für Christian Gnilka, hrsg. von Wilhelm Blümer, Rainer Helke, Markus Mülke (Münster: Aschendorff, 2002).

17 Pindarose kui „tumeda“ poeedi kuulsuse kohta, vt scholion tema Nemea 7. võidulaulu värss 89 juurde Anders Björn Drachmanni väljaandes Scholia vetera in Pindari carmina (Leipzig: Teubner, 1903) ja John T. Hamilton, Soliciting Darkness: Pindar, Obscurity, and the Classical tradition (Cambridge, MA: Harvard University Press, 2003), Pindarosest renessansiajal ning tema "tumedusest“ ja üleMA: Harvard University Press, 2003), Pindarosest renessansiajal ning tema „tumedusest “ ja üle-
vusest, vt Thomas Schmitz, Pindar in der französischen Renaissance. Studien zu seiner Rezeption in vusest, vt Thomas Schmitz, Pindar in der französischen Renaissance. Studien zu seiner Rezeption in 224 ja Stella P. Revard, Politics, Poetics and the Pindaric Odes: 1450-1700 (Tempe: ACMRS, 2009). 
ka pimeduse ja heleda valgusesära kontrasti motiivi, mis saab ülevuse allikaks, vt tema fragmenti 108b: On võimu jumalal ju mustast / ööst tõusta lasta säravat plekita valgust / ja päeva sära, puthtaimat / katta sünkja hämaruse / pilvega. Seda kontrasti pimeda öö ja heleda valguse puhul näeme romantilise ülevuse puhul, kõige silmatorkavamalt ehk maalikunstis, aga ka luules ja romaanis.

Kuigi Longinus ei räägi maalikunstist palju, on tema teoorias tähtsal kohal piltlikkus, täpsemalt kujutluspiltide loomine ( $\varphi \alpha v \tau \alpha \sigma i \alpha)$ :

15.1 Kaalukust, suursugusust ja teravust, mu noor sõber, aitavad neis asjus kõige paremini luua kujutluspildid - nii nimetavad mõned just mõttepiltide loomist. Sest üldiselt nimetatakse kujutluspildiks igasugust tekkivat mõtet, mis võib kõnet sünnitada, ent praegu on nimetus valdavalt kasutusel siis, kui sa arvad nägevat midagi, mida inspiratsiooni ja tunnete mõjul ütled, ning tood selle ka kuulajate pilgu ette.

Kujutluspiltide loomisele pühendab Longinus traktaadi 15. peatüki, tuues näiteid põhiliselt niisugustest stseenidest kreeka tragöödias ja Homerosel, kus kuulajat tabab midagi hirmu või kaastunnet äratavat, näiteks fuuriad, hukkumine või surmaoht, või siis midagi pühalikku. ${ }^{18}$ Ent üleva loomisel on suur roll ka teema leidmisel. Ülevate teemade hulka kuulub kõik jumalik ning üleinimlikud, äärmusi kujutavad pildid loodusest ja elust: kõrged mäed ja taevas, avar meri, hädaoht ja surm. ${ }^{19}$ Üleva tajumisel rõhutab Longinus tugevat analoogiat kunsti ja loodusjõudude vahel, seda väljendavad ka tema poolt näiteks toodud võrdlused: Homeros võrdleb suurejoonelisi lahinguid tule ja tormi möllamisega (9.10), ka looduses ei imetle kreeklased seda, mis on väike ja kasulik, vaid suurt - suuri jõgesid, ookeani ning vulkaanipurskeid:

... me ei imetle väikesi ojasid, kuigi nad on selgeveelised ja kasulikud, vaid Niilust, Doonaud, Reini, ja üle kõige Ookeani; ... kui oleme läitnud väikese tule,

18 Näited on Euripideselt (fuuriad ja Phaeton, kes sõidab üle taeva ja hukkub), Sophokleselt (fuuriad, kes jälitavad Orestest, ning surev Oidipus), Aischyloselt (vandeandmise stseen ja Dionysose epifaania) ning Homerose „Iliasest“ (lahing), aga ka kõnemeestest, kes panevad kuulajad ette kujutama mõnd hhingut või põgenenud vange - kõige allikaks kujutlus või mimesis (ptk 15.2-12)

9 Mägesid üksteise otsa kuhjavad Aloaadid (8.2), vaimusid kohale manav Aias (9.2), taeva suurus ja ülevus (9.5), jumalate lahing, mis paiskab segi maa ja taeva ning paisutab merd (9.6-8), valguse ja maa loomine Vanas Testamendis (9.9). Jumaliku rollist, vt ka de Jonge, „Dionysius and Longinus o the Sublime: Rhetoric and Religious Language“, 277-279.
.... ei ole me rohkem hämmastuses kui taevaste tulede puhul, mis sageli tumenevad, ega pea seda imeväärsemaks Etna kraatrist ... (35.4-5, vt ka lisa).

Võrreldes kirjandusega näeme kreeka ja rooma kunstis võimsa ülevusega seotud motiive ülivähe, sest maja sisekujundus pidi olema funktsionaalne ning klassikalisest ajast peale valitsenud harmoonilise ideaaliga ülevus eriti ei sobinud. Üks erandeid on gigantomahhia motiiv, mis esineb sageli nii kirjanduses kui kujutavas kunstis, ${ }^{20}$ sealhulgas skulptuuris. Samas näeme, et klassikaline stiil üritab kuidagi korrastada ja talitseda ülevat robustsust: Ateena akropoli Parthenoni templi kujunduse puhul on gigantomahhia steenid surutud ükshaaval metoopide rangetesse raamidesse ning nende rütm on hakitud, sest gigantide ja jumalate lähivõitluse stseenid vahelduvad kaarikusõidu stseenidega, ${ }^{21}$ erinevalt näiteks Pergamoni altarist, mille friise väline raamistik palju vähem piirab (vt ill. 1).

Ülev on Longinuse järgi ka tegevuse elav ja dramaatiline edastamine, nt Homerose „Iliase“ näites (ptk 9.13), ent see võib avalduda ka detailide valikus ja kokkupanekus, näiteks tormise mere ja laevahuku kirjeldused (10.5-7) ning äärmuslikud tunded, mis haaravad poetessi armastatut vaadeldes (Sappho fr. 31, Longinus, ptk 10.1-3). ${ }^{22}$

Niinimetatud võimsa ülevuse kõrval viitab Longinus ka teist tüüpi ülevale, mis seostub õrnuse ja peenusega. Siin leiab koha Sappho fragment 31, mille puhul on kokku pandud vastandid: mahedalt naerev ja vestlev neiu ning tema vaataja, kelle tabav tundepalang peaaegu poolsurnuks kangestab, aga üleva stiili loomise vahendiks on ka teksti üldine mahedus ning harmoonia, näiteks perifraaside (ptk 29) või sõnajärje ja rütmi (39-40) abil saavutatuna.

20 Vt gigantomahhia teemast vaasimaalidel: „Gigantomachy: Sculpture \& Vase Representations“ 21.09.2015, http://mkatz.web.wesleyan.edu/cciv1 10x/hesiod/ccivl10.gigantomachy.html (vaadatud 2.11.2016). Vt gigantomahhia motiivist kirjanduses: Doreen C. Innes, „Gigantomachy and natural Philosophy", Classical Quarterly, vol. 29 (1) (1979), 165-171.

21 Vt Katherine Schwab, „Parthenon East Metope XI: Herakles and the Gigantomachy“, America Journal of Archeology, vol. 100, 1 (1996), 89. Ateena akropoli muuseumis on eksponeeritud ka üsn jõulised ja robustsed skulptuurid algsest Hekatompedoni templist, vt http://www.theacropolismuseum.gr/en/content/hekatompedon (Heraklese vôitlus Tritoniga, vaadatud 02.11.2016). Arhailis templi asemele ehitatud Parthenonis on ürgsed voitlusstseenid (gigantomahhia, amazonomahhia kentauromahhia ja Trooja hävimine) metoopidel, vt http://www.theacropolismuseum.gr/en/content/
metopes-0 (vaadatud 02.11.2016). metopes-0 (vaadatud 02.11.2016)

Di „Dionysius and Longinus on the Sublime: Rhetoric and Religious Language“, 279-280. 


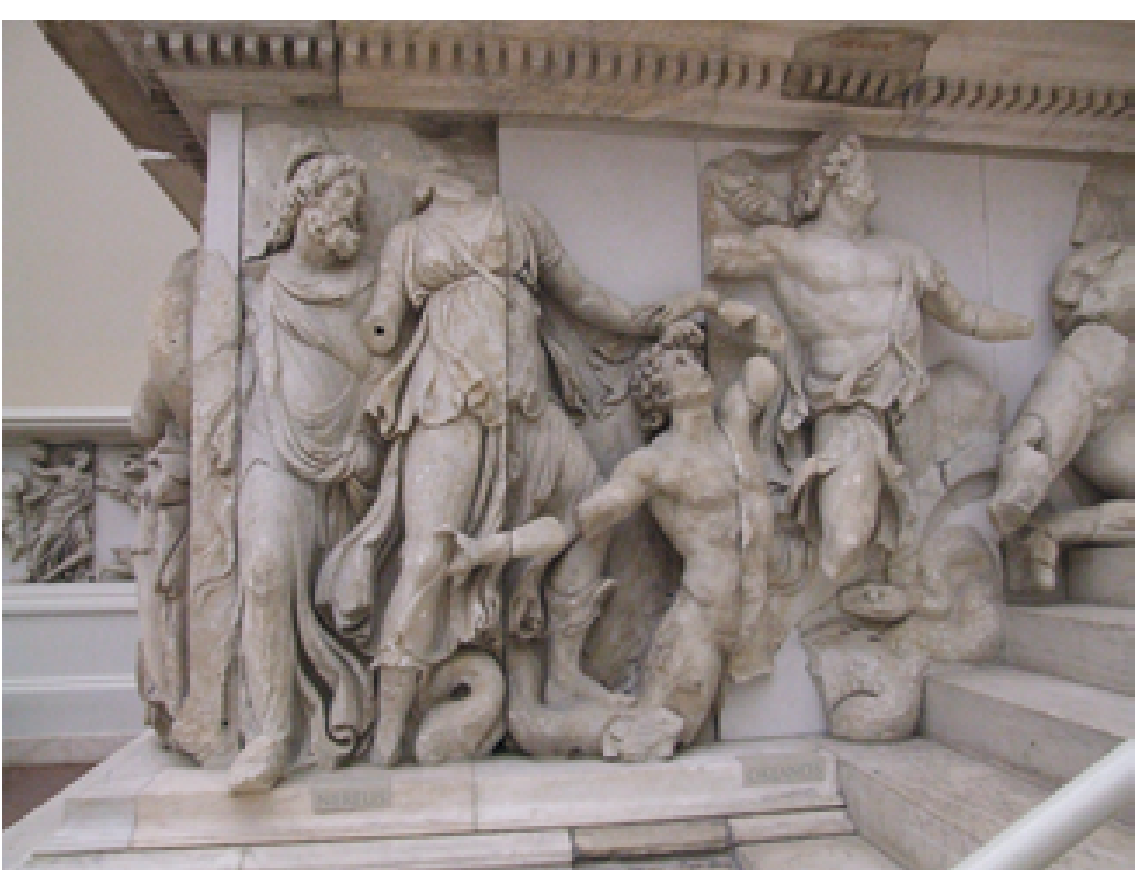

Ill. 1. Gigantomahhia. Pergamoni altari läänefriis. Berliin, Pergamoni muuseum. Foto: Claus Ableiter, Wikimedia Commons

Nagu tema eelkäijad Aristoteles, Demetrios ja Cicero, tunnetab Longinus rütmi tugevat mõju kuulajale. Ta peab seda oluliseks ülevuse allikaks, kuid keskendub peamiselt hoiatustele vältida tantsulisusega seostuvaid trohheilisi ja pürrhilisi rütme ning ülemäära monotoonset rütmilisust, ${ }^{23}$ mis juhiks tähelepanu teema ülevuselt kõrvale ning võib panna kuulaja jalaga takti lööma, otsekui tantsides (ptk 41).

\section{LONGINUSE TAASAVASTAMINE UUSAJAL}

Keskajal piirdus üleva ja ülevuse käsitlemine peamiselt religioosse ülevuse aspektiga, lähtekohaks Pseudo-Dionysios Areopagita Müstilise teoloogia suund üleva ja ekstaasi käsitlemisel. ${ }^{24}$ Longinuse traktaat ja ülevus kirjanduses taasavastati 16. sajandil, kui Johannes Oporinus trük-

23 Sellest vt altpoolt Byroni käsitluse juurest.

24 Vt Charles M. Stang, „Negative Theology from St. Gregory of Nyssa to Dionysius the Areopagite“ The Wiley-Blackwell Companion to Christian Mysticism, ed. by Julia A. Lamm (Oxford: Blackwell Publishing Ltd, 2013), 161-176. kis Baselis Francesco Robortello poolt editeeritud kreekakeelse teksti esmaväljaande (Longinus, 1554). Traktaat „Ülevusest“ levis aegamööda paralleelselt mõiste enesega, näiteks nimisõna sublimity on inglise keeles atesteeritud 1526. aastast ning adjektiiv ja verb 16. sajandi-17. sajand vahetusest, ent kirjanduslikule stiilile hakkas see viitama alles 17. sajandil. ${ }^{25}$ Esialgu ei olnud kunst ja kirjandus kõige altimad ülevaid stseene kujutama. Näiteks 16.-17. sajandi uusklassitsistlik luule hindas eelkõige harmoonilisi looduspilte, selgeveelisi ojasid ja kultuurmaastikke, ülevaga seostuvad motiivid olid selles üliharvad, pakkudes kontraste ja vajalikku kõrvalekallet üldisest tasakaalust ja teenides seega harmonia discors'i paradigmat. ${ }^{26}$

Longinuse traktaadi levik hoogustus 17. lõpul ja 18. sajandil ning see sai eriti populaarseks Nicolas Boileau kommenteeritud tõlke kaudu, mille Boileau avaldas samas köites omaenda „Luulekunstiga“ (Boileau, 1674). ${ }^{27}$ Boileau rõhutas sissejuhatuses tõlkele (nagu ka omaenda „Luulekunstis“), ühiskondliku mõõtme tähtsust: tema jaoks on Longinuse traktaat meistriteos, mis ilmutab nii tervet mõistust (bonsens), eruditsiooni kui elokventsi, see tähendab poliitikule hädavajalikke omadusi. Boileau jaoks polnud Longinus niisiis ainult suurepärase stiili- ja stiilitajuga kriitik, vaid ka (või isegi eelkõige) poliitik ja filosoof. ${ }^{28}$

Boileau rõhutab, et Longinus ei räägi eeskätt ülevast ehk kõrgstiilist, vaid ebatavalisest ja imeväärsest, mis kõne puhul rabab ja toob kaasa selle, et teos võlub ja kannab kuulaja endaga üles: ülev stiil nõuab alati suuri sõnu, ent ülevus võib leiduda väga lihtsas mõttes. Kõrgstiili ja lihtsa

25 Prantsuse keeles puhul seostub sublime’i stiilile viitav tähendus Boileau traktaadi mõjuga, kuig sõna ise on atesteeritud sajandeid varem, saksa keeles sai Erhabenes vastava tähenduse alles 18. sajansõna ise on atesteeritud sajandeid varem, saksa keeles sai Erhabenes vastava tah
dil, vt Päll, „Ülevuse anonüümne techne: Ps-Longinuse traktaat ülevusest“, 58.

26 Vt Fl, „Wlevase al 26

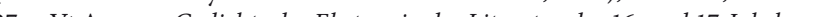

Vt Augner, Gedichte der Listase in der Literatur des 16. und 17. Jahrhunderts; Fritz, Vom Erhabenen: der Traktat "Peri Hypsous" und seine ästhetisch-religiöse Renaissance im 18. Jahrhundert; Cressida Ryan „Burke's Classical Geritage: Playing Games with Longinus“, The Science of Sensibility: Reading Burke's Philosophical Enquiry, ed. by Koen Vermeir, Michael Funk Deckard (Dordrecht, Heidelberg London, New York: Springer, 2012), 225-245; Demetrio St. Marin, Bibliography of the "Essay on the Sublime “(IEPI YYOY 2 ) (Leyde, Pays-Bas: D. St. Martin, 1967); Giuseppe Martano, „Il 'Saggio sul der Römishen Welt II (Berlin, New York: Walter de Gruyter 1984),374-403: Luigi Russo, Da Legging der Römishen Welt, II (Berlin, New York. Walter de Gruyter, 1984), 374-403; Luigi Russo, Da Longino a Longino. I luoghi de Sublime (Palermo: Aesthetica edixioni, 1987); Päll, „Ülevuse anonüümne techne

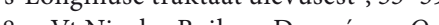

28 Vt Nicolas Boileau-Despréaux, Oeuvres diverses ... avec le Traité du sublime ou du merveilleux dans le discours, traduit du grec de Longin (Paris: Veuve de la Coste, 1674), Traité, p.* [1r] (ehk eessõna sissejuhatuses kui näitevalikus, mis keskendub poliitilise kõne kunstile. 
ülevuse vastandust illustreerib ta Longinuse näitega Genesisest (1.3, Longinusel ptk 9.9), mille Boileau parafraseerib kahe aleksandriiniga:

le souverain arbitre de la nature;

d'une seule parole forma la lumière.

(See, kes kohtumõistja ülim on loodusel,

üheainsa sõna abil lõi valguse.)

Sellele vastandab Boileau Longinuse tsiteeritud lihtsa Genesise lausungi: Saagu valgus! Ja valgus sai. ${ }^{29}$

Suurt austust Longinuse vastu (aga ehk ka kerget irooniat) 18. sajandil kajastab võib-olla kõige paremini Alexander Pope:

Söakas Longinus, inspireerimas sind üheksa; neilt, kriitik, armu kingina poeedi tule saad.

- Siin usub innukalt missiooni kohtumees,

kuid otsus õiglane tal, ehkki lõõmab meel;

ta seadust enda näitel kinnitab

ja ise ongi ülev, millest ammutab. ${ }^{30}$

Ülevuse teemat arendas edasi Edmund Burke traktaadis „A Philosophical Enquiry into the Origin of Our Ideas of the Sublime and Beautiful“ (1756). Burke uurib ülevust eelkõige filosoofina, taustaks Aristotelese teleoloogia, kategooriate käsitlus ja poeetikateooria ning samuti aristotellik arusaam ühiskonna olulisusest. Jätkates Aristotelese, Boileau ja Longinuse liini, uurib Burke ülevust nii looduses kui ühiskonnas, lähtudes selle päritolu puhul ennekõike tundeist (passions, mis nagu kreeka pathos'ki on kogemine üldiselt): valust, ohutundest, hirmust. ${ }^{31}$

29 Vt Boileau-Despréaux, Oeuvres diverses ... avec le Traité du sublime ou du merveilleux dans le discours, traduit du grec de Longin, Traité, p.*[4v] (ehk eessõna viimane lehekülg). Samas nähakse Boileau'd väga olulise üleva stiili ja ideestiku vahelise seose valjatoojana, vt Olsen, The Ut Pictur Poesis Tradition and English Neo-Classical Landscape Poetry, 188

30 Alexander Pope, ,Essay on criticism““ (1709), The Project Gutenberg EBook of An Essay on Criticism, http://www.gutenberg.org/files/7409/7409-h/7409-h.htm (vaadatud 02.11.2016), v. 675-680 31 Burke' i puhul tuuakse välja ülevuse seitse põhilist aspekti, mis esinevad loodusnähtuste puhul: tumedus (mis paneb täpsemalt vaatama), hämarus, ilmaolek, tohutu suurus (mis ületab taju vastuvotuvoime), valjusus ja akilisus, vt Christine Riding, Nigel Llewellyn, „British Art and the Sublime The Art of the Sublime (Tate Research Publication, 2013), https://www.tate.org.uk/art/research-pu-

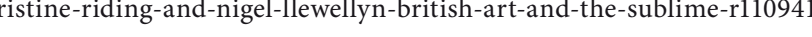
(vaadatud 02.11.2016).
Ülevuse mitmete aspektide käsitlustes on Burke'i oluliselt mõjutanud aristotellik filosoofia. Tema ülevate nähtuste liigituse üheks põhialuseks saab pidada privatsiooni, ilmaoleku kategooriat, mis avaldub valguse ja selguse, normaalse mõõtkava, valjususe ja rütmi puudumises. ${ }^{32}$ Longinusel, kes keskendub ennekõike kirjandusele, esinevad mitmed neist joontest, ent mitte privatsiooni, vaid ülemäära ja suuruse ( $\pi \varepsilon \rho \iota \sigma \sigma o ́ v$ $\mu \varepsilon ́ \gamma \varepsilon \theta \circ)$ kaudu defineerituna: tohutus, suursugusus, validus, äkilisus on kõik normaalset määra ületavad karakteristikud.

Teisena on aristotellikule filosoofiale tagasiviidav (läbi tomismi ja humanismiaja teooriate) Burke'i taotlus vaadelda ülevat ja ilu kahe põhjuse, causa finalise (eesmärkpõhjus) ja causa efficiensi (tegevpõhjus, loovpõhjus) tulemusel..$^{33}$ Lisaks sisulisele aspektile, st teleoloogilisele lähenemisele, on põhjuste väljatoomine kooskõlas ka 17. sajandit valitsenud ja 18. sajandil taanduma hakkava ramistliku lähenemisega kõigile teadustele: kõned (ja teaduskäsitlused) tuli üles ehitada rangete reeglite järgi, mille hulka kuulus ka lähtumine neljast põhjusest. ${ }^{34}$

Kolmandaks viitab Aristotelesele suursugusus, üks loomujooni, mida Aristoteles käsitleb nii „Poeetikas“ kui „Retoorikas“ ja mis on kesksel kohal tema eetikas. ${ }^{35}$ Suursugusus, mille puhul Aristoteles hoiatab äärmuste eest, seostub Burke'il aga eelkõige tavalist määra ületavaga. Neljandaks, ja paljude käsitlejate arvates peamiseks Aristotelese mõju allikaks on tema tragöödia definitsioon „Poeetikas“, millele Burke'il kajab vastu hirmu ja valu käsitlemine, tragöödia mõju kohta on tal koguni omaette peatükk (I.15). ${ }^{36}$

32 Vastavalt privation (Burke, ptk II.6), obscurity (II.3-5), difficulty (II.12), vastness, infinity (ptk II.7-11), loudness (II.17) suddenness (II.17). See kategooria on olul ine Aristotelese Füusikas (2.1, Bekkeri editsioonis 193b). Burke' i privatsiooni aristotelesliku tausta kohta on vähe kirjutatud, selle kategooria tähtsusest varauusajal, vt Brian Embry, „An Early Modern Scholastic Theory of Negative Entities: Thomas Compton Carleton on Lacks, Negations, and Privations", British Journal for the History of Philosophy, vol. 23, 1 (2015), 22-45.

33 Vastavalt I ja IV osa. Burke toetub tajude kausaalsuse käsitlemise osas Descartes' ile ja Hobbesile vt Carsten Zelle, „Erhabene, das. IV. 17., 18. Jahrhundert“, Historisches Wörterbuch der Rhetorik. Bd 2, hrsg. von Gert Ueding (Tübingen: Max Niemeyer, 1994), 1368; Pasquale Porro, „Ursache/Wirkun -II", Historisches Worterbuch der Philoso Nide, Bd. 11 (Base: Schwabe 2001), 386.

34 Vt ramistlikke vaateid kajastavat ülimõjukat Alstedi entsüklopeedia käsitlust, Lib.VIII, Cap. 7-10 Alsted, Encyclopaedia, septem tomis distincta (Stuttgart-Bad Kannstadt: Frommann, 1989), 412-414) 35 Vt „Poeetika“, 1459b, „Retoorika“, 1362b, 1366b, 1367b ja 1414a ning eriti „Nikomachose eetika“ $1107 \mathrm{~b}, 1122-23$.

36 Ka Longinus on osutanud tunnete (valu, haleduse ja hirmu) seosele ülevaga, vt 8.2 (Caeciliuse kriitika): Leidub tundeid, mis on ülevusest kaugel ja madalad, nagu kaastunne, leinad ja hirmud, aga ka palju ülevat, millega ei kaasne tundeid. Hirmu roll tuleb esile Longinuse vôrdlustes, kus ülevaks ülevad Homerose ja Demosthenese näited), vt 10.6 ja 34.4 (vt lisa). 


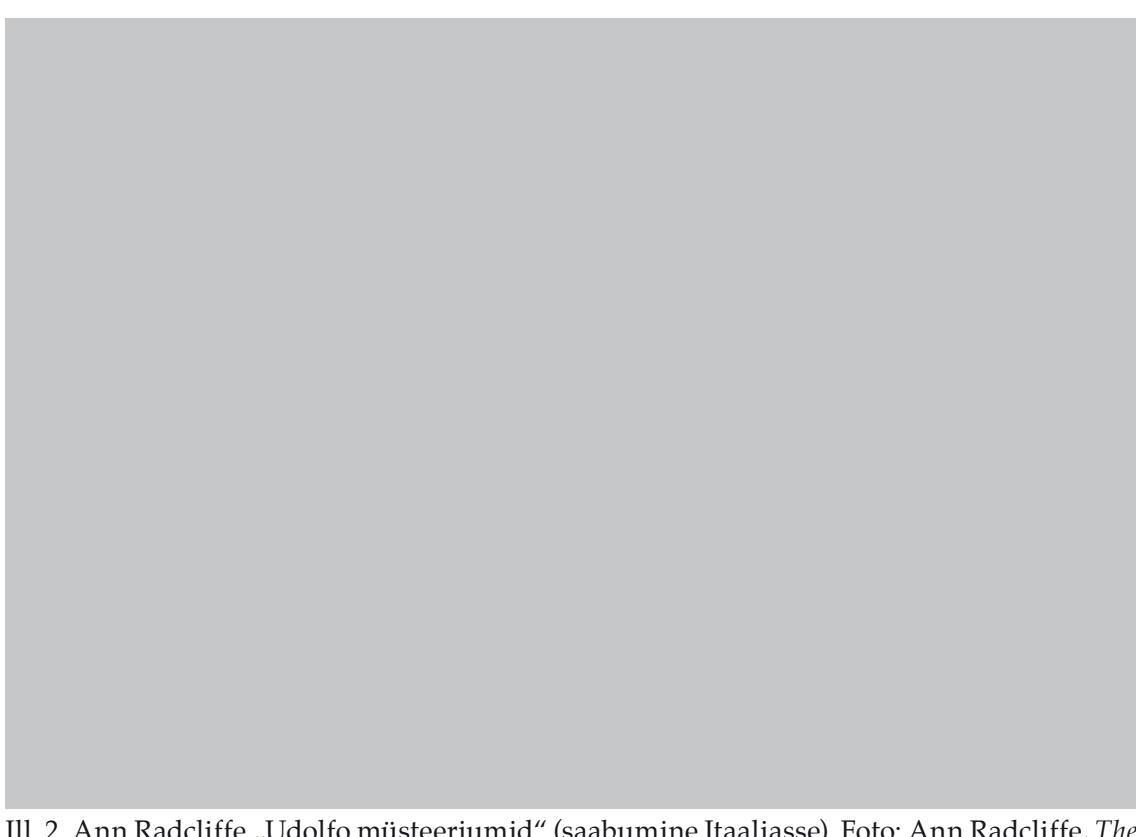

Ill. 2. Ann Radcliffe „Udolfo müsteeriumid“ (saabu
Mysteries of Udolpho (London: J. Limbird, 1836), 110.

Burke'i näited on pärit enamasti kirjandusest, teda loetakse gooti romaani pildikeele käsiraamatuks. Selle klassikaline näide, Ann Radcliffe'i „Udolfo müsteeriumid“ on täis otsekui Burke'ilt maha kirjutatud maastikukirjeldusi (vt ill. 2): ${ }^{37}$

Nad lahkusid oma tõldadest ja alustasid tõusu Alpidele. Ja siin avanesid nende ees sellised ülevuse vaatepildid, mille maalimist ei tohiks söandada mitte ükski, värvikaimgi keel. ... Näis, et Emily oli tõusnud mingisse teise maailma ja jätnud allpoolsesse maha iga tühise mõtte, iga tühise tunde: vaid suurus ja ülevus avardasid nü̈̈d tema vaimu ja ülendasid tundeid tema südames.

37 Gooti romaanist, vt Max Fincher, „The Sublime“, The Encyclopedia of the Gothic, ed. by William Hughes, David Punter, Andrew Smith (Malden, Oxford: Wiley Blackwell, 2016), 656; Burke'i näidete oendit vt Ryan „Burke’s Classical Geritage: Playing Games with Longinus“. Illustratsioonid Radcliffe teostele sõltuvad ajastust ja väljaandja valikutest, kohati rõhutatakse hirmuäratavat, kohati hoopis taandatakse (Teri Doerksen, „Framing the Narrative: Illustration and Pictorial Prose in Burney an Text ed by Christina Ionesu (Can Lee Text, ed. by Christina Ionescu (Cambridge: Cambridge Scholars, 2011), 498). Naide ptk 15 (1794, vol. Mark Algee-Hewitt Ariticism and the Sublime“" The Encyclopedia of British Literature 1660-1789, vol. 1, ed. by Gary Day, Jack Lynch (Malden, Oxford: Wiley Blackwell, 2015).
Kuigi Radcliffe'il on üleva meelisnäiteks Alpid, mis pakuvad kõigist mägedest kõige subliimsemaid vaatepilte ${ }^{38}$, võib see tunne tema kangelannat Emily't haarata ka merel:

... kui ta vaatles vaikides avarat silmapiiri, mis paindus kaugel ookeaniääre kohale, võitles kõikehaarava ülevuse tunne teda ähvardava hädaohu tajumisega. ${ }^{39}$

Selles Radcliffe'i näites näeme Burke'i poolt välja toodud hirmu rolli ülevuse loomisel (gloomy grandeur, dreadful sublimity) ${ }^{40}$. Hirm ja nauding on koos romaani lõpu lähedale lisatud tsitaadi James Beattie 1771. aastal loodud poeemist „The Minstrel, or, The Progress of Genius“:

What dreadful pleasure! There to stand sublime / like shipwrecked mariner on desert coast! (Mis õudne nauding! Seista ülevana seal / kui hüljat' rannal hukkund laeva meremees! $)^{41}$

Radcliffe'i poolt tsiteeritud kohale eelnevad Beattie'l kaks rida, mis pakuvad veel üht üleva (mere)pildiga seostuvat motiivi, udu:

And oft the craggy cliff he loved to climb,

When all in mist the world below was lost.

(Ta ronis tihti kaljurünkale, kus ees

tal kadus allpool uduvoos maailm. $)^{42}$

Võimsa ülevusega juba antiikajast saadik seostuvaile piltidele - ookean (meri), tuli, torm ja mäed - lisanduvad nii kirjanduses kui maalikunstis varemed, maailma kaduvuse sümbol. ${ }^{43}$ Näiteks William Wordsworthi luuletus „Peele'i loss" (... And this huge Castle, standing here sublime) on inspireeritud sir George Beaumont'i maalist „Peele'i loss tormis“ (vt ill. 3):44

38 Radcliffe, The Mysteries of Udolpho, 81, 107.

39 Ibidem, 234

40 Vt ibidem, 109

$\begin{array}{ll}40 & \text { Vt ibidem, } 109 \\ 41 & \text { Vt ibidem, } 294\end{array}$

42 Minstrel, 1. raamat XXI, James Beattie, Minstrel, with Some Other Poems (Edinburgh: James

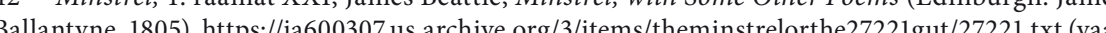
datud 02.11.2016)

43 Selle on kokku võtnud Tate'i galerii projekt, vt Riding, Llewellyn, „British Art and the Sublime“. Vt ka Varemed. Ruins, toim. Juhan Maiste, Kadi Polli (Tallinn: Eesti Kunstiakadeemia Restaureerimiskool, 2004). 44 Vastastikust mõju nähakse ka Turneri ja Coleridge'i puhul ning mujalgi, vt Humprey House, 4he Ancient Mariner" '. English Romantic Poets. Modern Essays in Criticism, ed, by Meyer H. Abram "The Ancient Mariner", English Romantic Poets. Modern Essays in Criticism, ed. by Meyer H. Abram Vision: Constable and Wordsworth (Wisconsin. The University of Wisconsin Press, 1975), 44-45. 


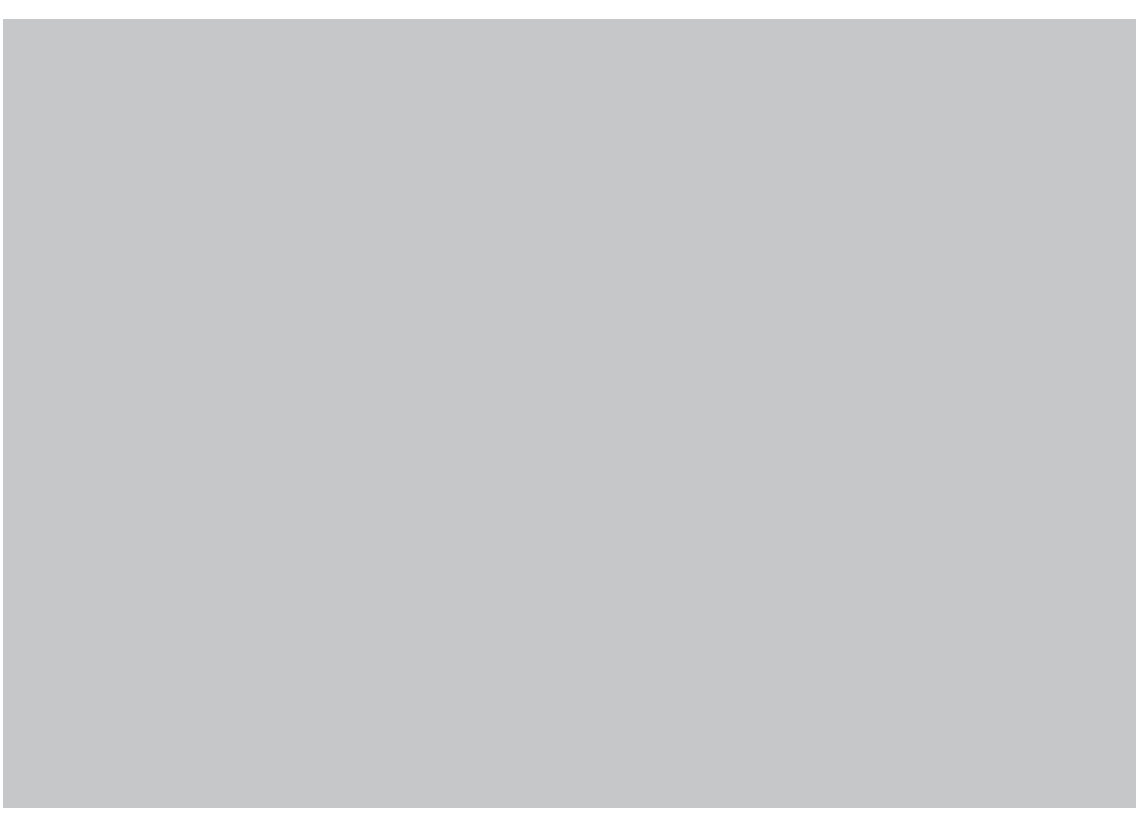

Ill. 3. George Beaumont, Peele'i loss tormis, õli lõuendil, 1806. New Walk Museum \& Art Gallery, Leicester Arts and Museums Service. Foto: Wikimedia Commons.

Saksa maalikunstis on ülevuse paradigmaatiliseks näiteks saanud Caspar David Friedrich, kelle motiive võib Eestis näha August Matthias Hageni loomingus. ${ }^{45}$ Saksamaa mõju näeme ka kirjanduse puhul, inspiratsioonis, mida luuletajad (Goethe, Hölderlini, George) pakkusid baltisaksa ning eesti luuletajatele.

\section{ÜLEV MAASTIK EESTI KIRJANDUSES}

Saksa romantilise transtsendentsiiha ja Caspar David Friedrichi vaimus maalis August Matthias Hagen Euroopast pärit motiivide - Alpide ja udu - kõrval ülevuse paradigmaga sobivaid paiku ka kodule lähemalt,

45 Caspar David Friedrichi ülevuse paradigmaatiliseks näiteks on kujunenud Mönch am Meer (1810), ent ka tema kontrastsete valguse ja varjudega mägi- ja metsamaastikud vastavad sellele ideele. cf. Gerd-Helge Vogel, August Matthias Hagen (1794-1878) - Deutschbaltische Landsch G, 2001) c. Gerd-Helge Vogel, „August Mathias Hagen (1794-1878) - Deutschbaltische Landschaftsmalere History, 10 (2015), 11-52.

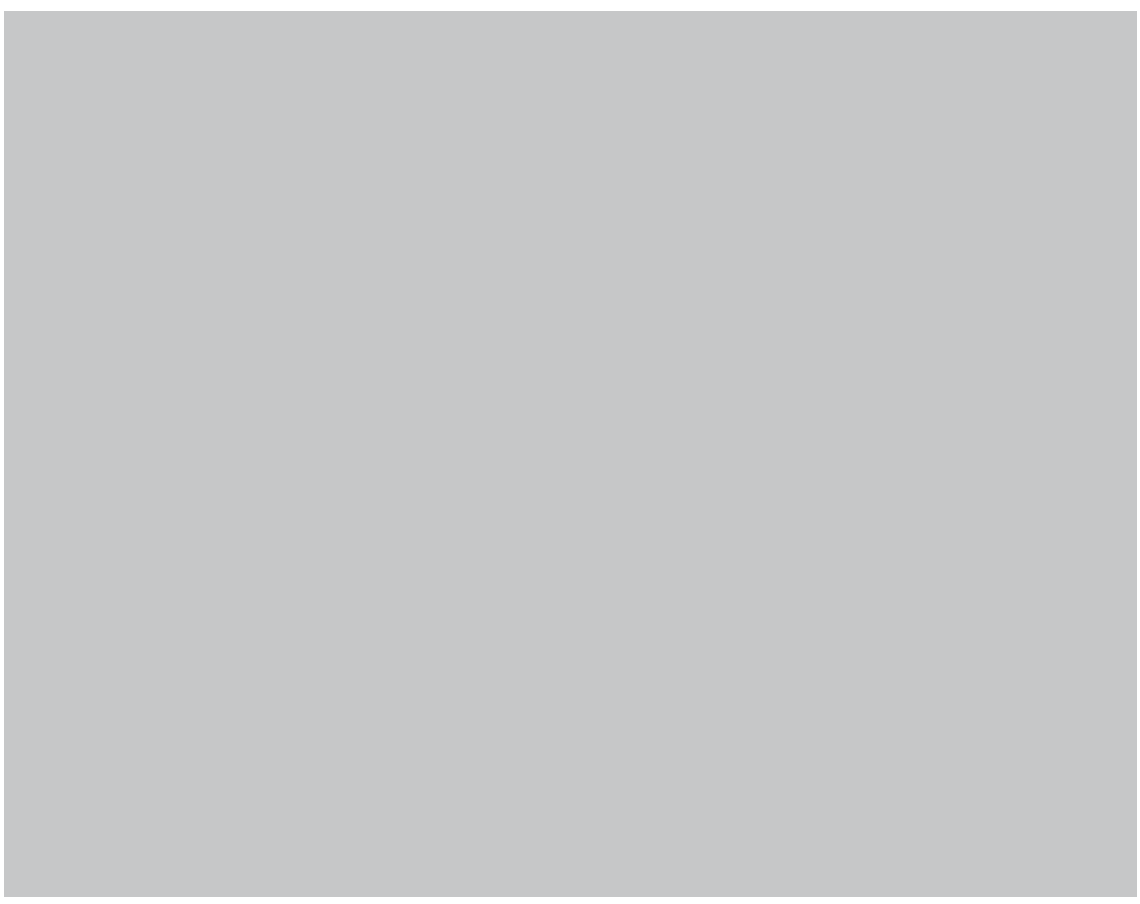

Ill. 4. August Matthias Hagen, Koknese maastik, akvarell, tušš, 1833. Tartu Ülikool raamatukogu.

näiteks Koknese ja Suursaare maastikud. ${ }^{46}$ Iseäranis Koknese maastik näitab Alpide mustri (kaljud, vahutav vesi, pisut ähvardav taevas) ülekandumist põhja, kuid teisenenuna, hoopis realistlikumas ja vaoshoitumas laadis ning pastelsetes toonides (vt ill. 4).

Suurejoonelised maastikupildid jõudsid ka maarahvale mõeldud kirjavarasse, ülevaid emotsioone äratama sobis näiteks Narva joa kui imelise ja hirmuäratava loodusnähtuse kirjeldus 1858. aasta Eesti Maarahva kalendris. ${ }^{47}$ Samasugused romantilised kaljud ja nendelt alla vahutav vesi, mida näeme Radcliffe'il ja saksa romantilises luules, said ülevuse allikaks ka Eesti Pindarosel, Kristjan Jaak Petersonil. ${ }^{48}$

46 Vt illustratsioone, Vogel, „August Matthias Hagen (1794-1878) - Deutschbaltische undschefom taliste maastike tüupidest baltisaksa maalikunstis, Ingrid Sahk, Loodus pildis. Maastikumotiivid eest

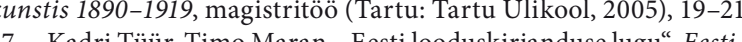

47 Kadri Tüür, Timo Maran, „Eesti looduskirjanduse lugu“, Eesti looduskultuur, toim. Timo Maran, Kadri Túr (Ta, Tim

odide vaimuloolisest taustast" Keel ja Kirjandus, 2 (2012) 105 (kogu artikke: Keel ja Kirjandus, 1 (2012), 11-29; Keel ja Kirjandus, 2 (2012), 103-122). 
Pindaros oli Longinuse jaoks paradigmaatiline ülev poeet nagu Homeroski, mõlemad olid kõige kõrgemalt hinnatud vigadest hoolimata (vt lisa). Longinuse esimene väljaandja Francesco Robortello ei piirdunud filoloogitööga ning Longinuse ülevust käsitleva ning suurte poeetide jäljendamist soovitava traktaadi väljaandmisega, vaid jäljendas neid ka ise, avaldades 1548. aastal oma kreekakeelse Pindarose stiilis oodi. Pindarose jäljendamine oli 15. sajandist 19. sajandi alguseni Euroopa ooditraditsiooni keskseks arendavaks ja alalhoidvaks jõuks, olenemata sellest, kas luuletati vanakreeka ja ladina või rahvuskeeltes. ${ }^{49}$ Kristjan Jaak Peterson luuletas küll eesti keeles, ent siiski Pindarose eeskujule toetudes. Seda on näha nii konkreetsete motiivide laenamises kui tema üldiselt Pindaroslikult söakas ja reeglipäratus stiilis, mis kaasneb suurejooneliste kujutluspiltidega. ${ }^{50}$

Loodusmotiivide kaudu esitab Peterson kaks vastandlikku pilti kodumaa keelest ja luulest - kõigepealt enda väljendusjõust veel ebateadlik eesti keel, mis on kui rahuga jookslev tasane ojake heinamaal, sinise taeva kullases tules („Kuu“). Sellele vastandub ihaletav keeleideaal, tõeliselt üleva ja ülendava loomingu keel, mida iseloomustab taeva müristamine ja mere hüüdmine („,Kuu“), vahuse jõe mürisevad lained, mis kalju pealta langevad oru sisse, taeva pikne musta pilvede alla („Laulja“). Sellise üleva looduskaemusega taotles ta eesti keele ja luule väljatõstmist madalstiilist kõrgstiili, kuigi peaaegu saja aasta jooksul ei leidnud ta tunnustust ja järgijaid ${ }^{51}$ - tärkav Eesti luule ja kriitikud otsisid identiteeti rahvusromantismist.

Noor-Eesti poeedid, kelle aega kuulub ka Petersoni luule taasavastamine, läksid uut teed, ihates eemale „põllukraavi vulinast ja lõokese tiri-lirist “. ${ }^{52}$ Kristjanjaagulikult ülevat ja romantilist merd igatses Tallinnas Toompea vanglas istuv Friedebert Tuglas 1906. aastal:

49 Vt Janika Päll, „The Transfer of Greek Pindaric Ode from Italy to the Northern Shores: from Robortello to Vogelmann and further", Palingenesia (ilmumas 2016). Subliimsest Euroopa Pindarose stiilis oodis: Thomas Schmitz, Pindar in der französischen Renaissance. Studien zu seiner Rezeption P. Revard, Pindar and the Renaissance Hymn Ode: 1450-1700 (Tempe: Arizona Center for Medieva P. Revard, Pindar and the Renaissance Hymn Ode. 1450-1700 (Tempe. Arizona Center for Medieval and Renaissance Studies, 2001); Stella P. Revard, Politics, Poetics and the Pindatc Ode (Tempe. Arizona Center for Medieval and Rena, Ponce Studies/Brepols, 2009).

50 Vt Undusk, „Eesti Pindaros. Kristjan Jaak Petersoni oodide vaimuloolisest taustast“, 15.

52 Kruusi tsitaati vt Jüri Kivimäe, ,,Noor-Eesti tähendust otsides: vanu ja uusi mõsteid““, Noor-Eest kümme aastat: esteetika ja tähendus, Methis, 1-2 (2008), 28; vt ka ibidem, 36-40.
... lapsena ihanud, merd ääretut ..., lainete valgeid harju ... , laineid, mis veerevad randa kui tuiskavad leegid, mis raksuvad ..., mis mürinal maltrannale vaovad ... kui vägi, mis põgeneb vaenlase eest või põdrakari läeb põleva padriku eest, ... vägevat suurust, ... läheneva maru algust, ... sähvava välgu rohelist valgust, ... tuiskavate lainete vahtu. („,Meri“', 1908)

Isegi siis, kui Tuglase meri on vaikne, on see kui magava hiiglase raudrüüs rind. Poeet ihkab ülevust, suurust, vabadust - saaks suure mere randa! Ka vaikse pinna all on Tuglase meri vägev ja hirmutav, olles samas ka võimalik vabastaja, igapäeva elu väiksusest (ja vanglast) välja tooja ning ülendaja.

Eesti identiteeti on nähtud pigem tuultest pillutatud maa- ja metsarahva kui mererahvana, mistõttu luules võib omamaine ülevus seostuda hoopis lihtsa põlluveere ja nurmega. ${ }^{54}$ Kui Kristjan Jaagu laulja püüdles eemale lihtsa heinamaa tasase oja juurest ja Tuglas ihkas vabadust ääretu mere ääres, siis Villem Ridala leidis oma üleva eesti (kultuur) maastikel. Luuletuses „Põllu veerul“ (1927) on ühendatud sines särav meri ja taeva sinitelk, tulilille helkjas kuld ning laine hõbe helk, mis kokku loovad värvikireva, ent üleva pildi:

Põllu nõlval rohu haljus,

tulilille helkjas kuld,

kasteheinad, õite paljus,

rohu hõng ja lõhnav muld.

eemal meri sines särav,

laine läik ja hõbe helk,

ülal kõrge taeva värav,

kumm nii ülev, sinitelk. ${ }^{55}$

Ridalale iseloomulik, häälikukorduste loodud kõlapiltide vaheldumine visuaalsete piltidega viib ka siin selleni, et need võimendavad üksteist. ${ }^{56}$ Kui luuletuse rütm ei oleks nii pehme (enamikus värssidest esineb vähemalt üks, sageli paar lühikest lahtist silpi nn tugevas

53 Sõnarine. Eesti luule antoloogia 1, koost. Karl Muru (Tallinn: Eesti Raamat, 1989), 427-431. 54 Vt Önne Kepp, Identiteedi suundumusi Eesti luules (Tallinn: Tallinna Ülikooli kirjastus, 2008), $54-18$ $13-18$

55 Sõnarine. Eesti luule antoloogia 1, 455

作 esteetika ja tähendus, Methis, 1-2 (2008), 78-79. 


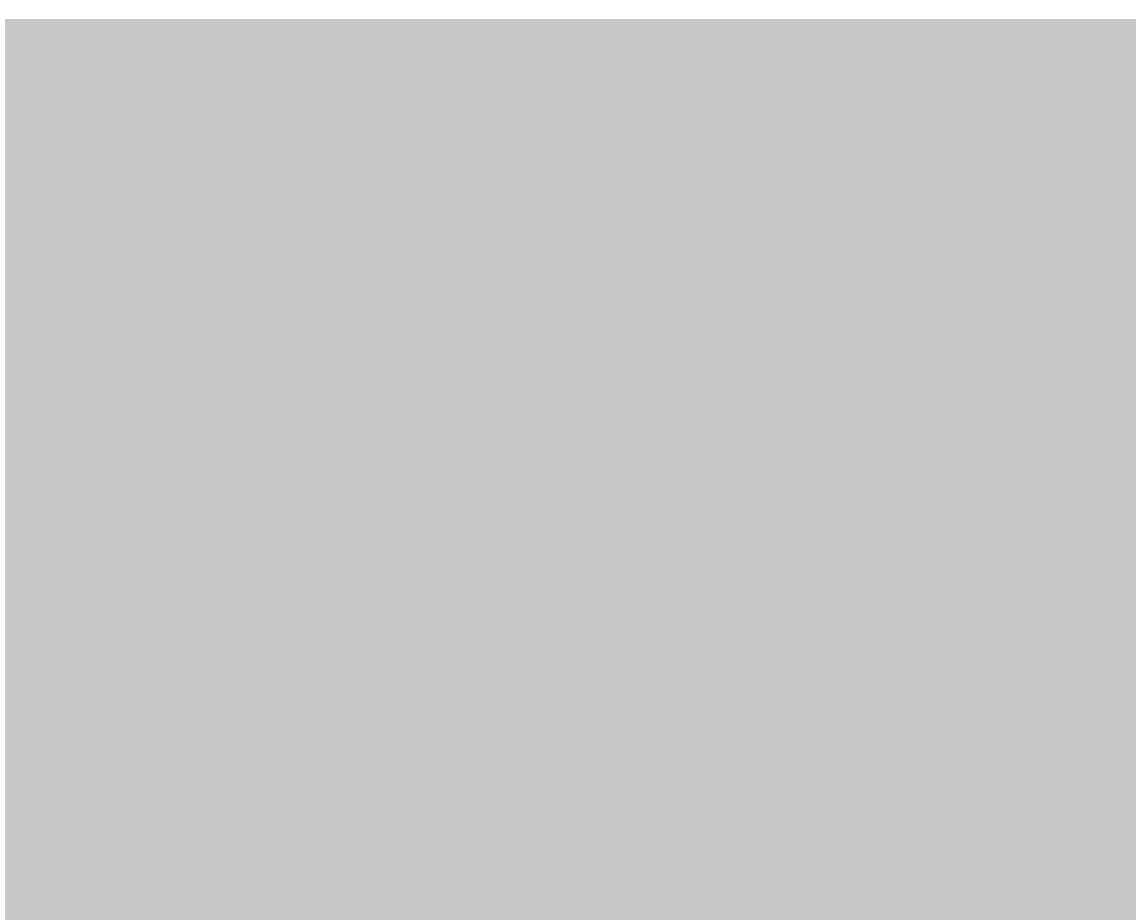

Ill. 5. Konrad Mägi, Saaremaa. Etüüd, õli papil, 1913-1914. Enn Kunila erakogu.

positsioonis, mis ei lase trohheilisel rütmil raiuvaks muutuda) ja kõlakordused ei seoks salme tervikuks, võiks see värvide loend mõjuda ohjeldamatuna. Samamoodi peaaegu ohjeldamatult, ja ebaeestilikult värvikirevana mõjub Konrad Mägi Saaremaa rannaniit, millel taevas ja meri tagaplaanile jäävad (vt ill. 5).

Üksikuist näiteist hoolimata näib mereteema 20. sajandi alguse Eesti maalikunstnikke ja poeete vähe köitvat, Ahvenamaa ja Capri romantiliselt ülevad vaated tunduvad paeluvamana kui Eestimaa hall taevas, ka pärast Noor-Eesti aega, niinimetatud eesti marinistide maalidel, on tihti esiplaanil pigem rannarahvas, paadid ja hooned kui meri. ${ }^{57}$

57 Vt Tiiu Talvistu, „Noor-Eesti ja kunstnikud“, Noor-Eesti kümme aastat: esteetika ja tähendus, Methis, 1-2 (2008), 234-235; Ingrid Sahk, „Reisidel ja kodus nähtud maastik. Mõningatest motiivides eesti kunstis 20. sajandi algul", Igatsus ja kohalejöudmine: töid Enn Kunila kogust (Tallinn: Sperare, näitest“" Noor-Eesti kümme aastat: esteetika ja tähendus, Methis, 1-2 (2008), 129-130, 133 (dekadentsist).

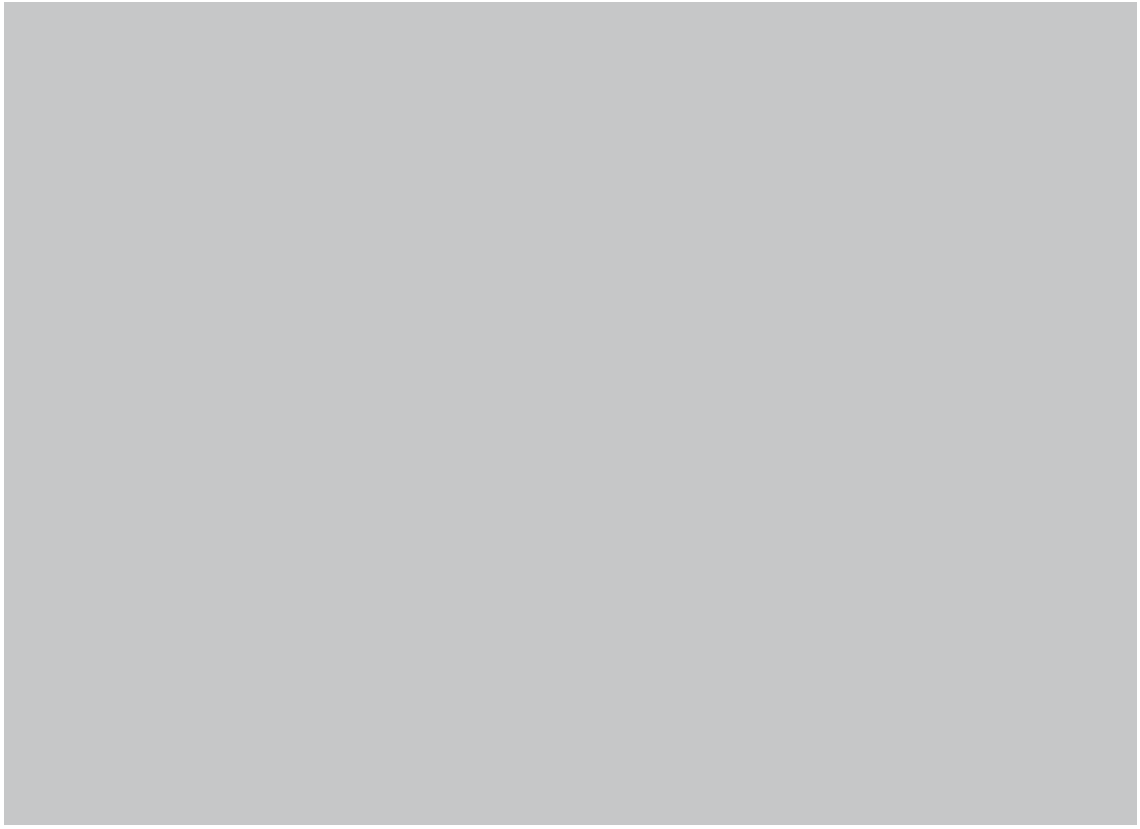

Ill. 6. August Matthias Hagen, Põhja-Eesti rand V, seepia, guašš, 1834. Tartu Ülikool raamatukogu.

Tagasi 19. sajandi alguse üleva motiivistiku juurde jõuame läbi ühe tõlke 20. sajandi keskpaigast. Minni Nurme (1917-1994) tõlkis 1950ndail eesti keelde George Gordon Byroni (1788-1824) luulet, sealhulgas ka tema 1815. aastal loodud salmid „Muusikale“. ${ }^{58}$ Byron esindab inglise sublime'i hilisemat koolkonda, mis hakkas levima 18. sajandi lõpust ja kus ülevuse mõõdet võis esindada muugi kui suuredimensiooniline: mägede kõrgusele, mere sügavusele, surmale ja ilmutuslikkusele lisandusid vaiksed tüüned maastikud. ${ }^{59}$

Nurme „Muusikale“ ei ole Byroni luuletuse puhtakujuline tõlge. Kõigepealt on muutunud adressaat ja koos sellega ka teema. Byroni salme võib liigitada armastusluuletuseks, mis kasutab vanatestamentlikke võrdlusi ${ }^{60}$ armastatu hääle ja muusika mõju vahel - muusika,

58 Minni Nurme tõlge, vt George Gordon Byron, Luuletusi ja poeeme (Tallinn: Eesti Riiklik Kirjastus 1957) ja inglise keeles George Gordon Byron, Byron's poems in three volumes, vol. 1 (London: Dent, New York: Dutton, 1963), 171

9 Riding, Llewellyn, „British Art and the Sublime“.

Voice of the LORD is over the Waters (tlk Issanda häal on vete päal... ), vt ka jätku: Issanda hääl murrab seedreid ... Issanda mürina hääl purskab tuleleeke. 
nõiduslik ilu tütar lummab ookeani, vaigistades oma maheda häälega selle lained ja tuuled. Nurme laul seevastu on ülistuslaul muusikale, mis äratab istuvas kuulajas kujutluspilte tuulevaikuses kuuvalgel ulgumerest (vt ill. 6), Byroni lõpusalm on tal peaaegu täielikult tõlkimata. Siiski annavad mõlemad edasi ülevat tunnet. Nurme eestikeelne versioon toob eksplitsiitselt välja pühaduse ehk jumaliku dimensiooni, mida inglise keeles pole vaja, sest religioosset registrit annab 4. salmis edasi kristlikele hümnidele viitav sõnavara: spirit bows before thee, adore thee, lisaks juba mainitud viide „häälele vete kohal“.

\section{Nurme, „Muusikale“, 1957}

Kõigist ilu tütreist pühim nõiduslikem oled sa, nagu sügav vetemühin tasa voogad, muusika! Helin silma ette manab ulgumerd, mis tüünelt lamab, rahunevat laintekaiku unelevat tuulevaikust.

Või kuis kuukiir ketti kujub üle mere, mille pind tõustes-vajudes nii sujuv nagu uinuv lapserind. Nõnda hing on kaasa kistud, kui sind kuulatades istun, tunded sügavad ja helged nagu meri suur ja selge.

Byroni salmide ülevus ei seisne pikselöögiga lajatamises, vaid ookeanisügavuste nõiduslikus, pehmes taltumises, mille toob esile ja rõhutab romantikuile nii armas kuukiir ja lainte sädelus. Mahedus (sweet voice), õrnus (gently heaving) ja pehmus (full, but soft emotion) peegelduvad ka rütmis, milles on ülekaalus kerged, rõhutud reaalgused (there be none $\mathrm{x}$ $\mathrm{x} X$ ) ja samamoodi laskuvad, nn naisrütmiga realõpud (Summer's ocean X x X x). Nurme tõlgendab Byroni rütmi selgelt trohheilise tetrameetrina, ${ }^{61}$ ent kui Byronil algavad kõik read kergete abisõnadega, mõjudes pigem joonikute, anapestide või jambidena, siis Nurme rütm on sümmeetriline ja tasase voogamise asemel mõjub kohati isegi pisut raiuvana. Tundub nagu peaks Byron meeles Longinuse õpetust vältida monotoonselt raiuvaid trohheusi, alustades ridu tihti kolmesilbiliste värsijalgadega, mis võitlevad inglise jambi (aga ka liigrange trohheuse) rütmi vastu. ${ }^{62}$ Siiski alustab ka Nurme ridu tihti kergete, lahtiste silpidega (tasa voogad, üle mere, nagu uinuv, nagu meri), nii et üldmulje ei ole liialt rõhuv.

Byron alustab ja lõpetab pehmelt ning jätab traditsioonilisemad ülevusega seotud motiivid (sügavuse, kuu sära) luuletuse keskele aktsendiks, Nurme ent toimib vastupidiselt, raamistades luuletuse äärmuslike dimensioonide rõhutamisega, nii alguses (püha, sügav vetemühin) kui lõpus (tunded sügavad ja selged, suur ja selge). Lisaks toob Nurme viimases salmis sisse hinge kaasakistuse motiivi, mis sobib hästi traditsioonilise üleva registriga.

Nii näivad Nurme tõlke motiivid pealtnäha ülevamadki kui Byroni originaal. Ent sügavuse ja suuruse ülerõhutamisega kompenseerib Nurme seda, mis üleva registri edasiandmiseks neljanda salmi tõlke puhul tegemata jäänud (palve, kummardamise moment). Mõlemad rõhutavad muusika mõju hingele, mis on juba antiigi kunstiteoorias (Gorgiasest Platoni ja Pseudo-Longinuseni) ülevuse üks tähtsamaid karakteristikuid: Nurmel kisub see inimese hinge kaasa, Byronil kummardab adressaadi ees inimese vaim. Samas rõhutab Byron ka muusika suurt mõju füüsilisele maailmale, vete kohal hõljuv muusika vaigistab ookeani, nii nagu Orpheuse muusika lummas loomi ja linde, puid ja isegi hingetuid kaljusid.

Tõlkija valikute põhjuseid on sageli raske määratleda: 1950ndatel avaldatud luules ei kohta me religioonile viitavat keelepruuki, ent Nurme pisut jõulisema looduspildi taustaks on ka eesti ooditraditsioon, eriti selle Kristjan Jaak Petersonist lähtuv liin, ning sõjajärgsete aastate nõudmine pateetilisevõitu ülevuse järele. Viimast aitab ehk selgitada paralleel muusikaga.

61 Stanislav Schvabrin, Nabokov as translaator (Dissertation of the Universitity of California: 2008), 203-204

62 Burton Raffel toob välja Byroni puhul kinnistunud rangete rütmiskeemide (eriti 5-jalalise jambi) ve 
Ähvardava ja suursuguse üleva teemat Eesti muusikas näeme Villem Kapi sümfoonilises poeemis „Põhjarannik“ meeskoorile ja orkestrile (1958). ${ }^{63}$ Juba koosseis, meeskoor (RAM) orkestri saatel, lubab kasutada ülevale omast suurt heli- ja tunnete amplituudi - loo orkestratsioongi ei hoia kokku värvidega. Võimalused selleks pakub Kersti Merilaasi 1957. aastal ilmunud tekst:

\author{
Rannik kui hüppel \\ rünnakuhoos, \\ manner ja meri \\ siin sülitsi koos. \\ Kivine kallas, \\ rind tuultele valla, \\ rahne ja rähka \\ siit virutab alla. \\ Vood aga vastasel \\ haarates jalust, \\ purevad, järavad \\ kaldaalust. \\ Seiske! Siit edasi \\ kumbki ei saa: \\ võimas on meri, \\ veel võimsam on maa. ${ }^{64}$
}

Klassikalises sonaadivormis on Merilaasi luuletuse tekst peateema aluseks, seda korratakse teose alguses ja lõpus kokku kolm korda, keskel on lüüriline kõrvalteema (laulukest leebet nüüd uinutab laine, valguse peegeldus vaiksel vool ... mis toob sisse meenuvad möödunud võitluse päevad kaaslased kallid ei meelest kao...), millesse muusikas aeg-ajalt siis murrab maa ja mere ähvardava vastasseisu teema. Kulminatsioonile - järavad purevad, purevad järavad - paneb punkti: Seiske! ei edasi saa, ei kumbki edasi saa - võimsam on meri, veel võimsam on maa. Ükskõik, kas interpreteerida

63 Villem Kapp, Põhjarannik (1959): klaviir (Tallinn: Eesti Riiklik Kirjastus, 1959). Kapi sümfooniline poeem on siin näiteks võetud mereteema ja ajastu kattumise tõttu. Margus Pärtlas on Villem Kap 2. sümfoonia liigitanud nôukogulikult ,ülevaks , vastandades selle jutumarkideta úlevale Tubina 5 . sumfooniale (Margus Partlas, „Eduard Tubina aeg, Teater. Munsika. Kino, 8-9 (2001), 62-63). Eest muusika puhul võiks ja peaks üleva käsitlemist alustama Rudolf Tobiase ",oonase lähetamisest"

64 Sõnarine. Eesti luule antoloogia 2, koost. Karl Muru (Tallinn: Eesti Raamat, 1992), 633.
Merilaasi luuletust kõrvalteema teksti arvestades sõja-allegooriana või Sibeliuse „Finlandiat“ jätkava põhjamaiselt üleva looduse ja loomuse kujutamisena, ${ }^{65}$ vaatepilt on ülev.

\section{KOKKUVÕTTEKS}

Merepiltide puhul 20. sajandi eesti kunstis ja luules näeme küll aegajalt kordumas romantilisest saksa kunstist väljakasvanud motiive, mis iseloomustasid juba 19. sajandi algupoole kunsti, ent samas on näha ka suursuguse ja karmikoelise ülevuse taandumist kontempleerituma ja harmoonilisema üleva ees. 20. sajandi lõpul tunduvad vähmalt mereteema puhul valdavat õrnad ja peened toonid, nii Aili Vindi maalides (kes isegi Estonia laevahuku teema puhul kujutab pigem tormile järgnevat hommikut kui tormi ennast) kui Ester Mägi muusikas. Kas eesti luule ja maalikunst leiavad 21. sajandil vahepeal unustusse jäänud suursuguse üleva? Motiive loodusest leiaks: on pankrannik, hiidrahnud ja tormid, lisaks on 20. sajandi lõpupoole fotokunsti ilmunud ähvardava varjundiga rüsijää ja tuhamägede motiivid, kuid suurejoonelise üleva jäädvustamist näib taotlevat eelkõige loodusfoto. Usun, et ka kirjanduses ja kujutavas kunstis ei jää võimas ülevus taasleidmata, aeg selleks - üle maailma - on küps.

LISA:

\section{GENIA ALSEST EBATÄIUSLIKKUSEST ${ }^{66}$}

32.6. Neid ja tuhandeid teisi sellesarnaseid metafoore on ridamisi; neist aitab selgitamaks, et troobid on loomu poolest suursugused ja et metafoorid loovad ülevust ning et tundeliste ja kirjeldavate kohtade jaoks on need enamasti väga tänuväärsed. Ometi ahvatleb troopide kasutus - nagu mungi kaunis sõnaseadmisel - alati mõõdutundetusele, mis on selge ka minu ütlemiseta. 7. Selliste asjade tõttu ei sugeta Platonit mitte vähe, sest sageli laseb ta mingist kõnejoobumusest end kanda mõõdutute ja järskude metafooride ning allegoorilise ülespuhutuse juurde. Ta ütleb nimelt [Seadused VI.773c]: "Pole lihtne ette näha, kuidas linn peab olema kokku segatud just nagu krateeris, kuhu valatuna hullunud vein küll muliseb, ent teise, kaine

65 Analüüsi vt Helga Tõnson, Villem Kapp (Tallinn: Eesti Raamat, 1967), 87-90, tema jaoks on 
jumala poolt korrale kutsutuna leiab hea seltskonna ning saab heaks ja mõõdukaks joogiks." Öeldakse niisiis, et veini kaineks jumalaks ja segamist korralekutsumiseks nimetada saab tõepoolest vaid poeet, kes pole ise kaine. 8. Selliseid vigu rünnates söandas ju ka Caecilius oma käsitluses Lysiasest kuulutada Lysiase igati paremaks kui Platoni, olles pidevalt kahe tunde kütkes. Nimelt, kuigi ta armastab Lysiast nii nagu ta ennastki ei armasta, vihkab ta Platonit siiski igati rohkem kui armastab Lysiast. Pealegi ei ole ta teesid vaenamiskire tõttu aktsepteeritavad nõnda nagu ta on arvanud. Sest tema eelistab oma kõnemeest kui veatut ja plekitut, kuna aga Platon olevat igati ekslik. See aga ei ole sugugi niimoodi, isegi mitte ligilähedaselt.

33.1 Võtkem näiteks üks tõeliselt selge ja laitmatu kirjanik. Kas ei tasuks siin läheneda asjale üldiselt, küsides: Mis on poeesias ja proosas parem, kas suurus mõnede eksimuste keskel või mõõdupidamine koos täieliku korrektsusega, mis on täiesti puhas ning laitmatu? Ja veel, Zeusi nimel, kumba on õigustatum pidada kirjanduses esimeseks, kas suuremat hulka voorusi või suurimaid? Just need küsimused on igas suhtes pärisomad ülevuse uurimisele ja vaatlusele. 2. Ma tean, et ülisuured natuurid on üliharva plekitud, sest igati täpne riskib väiksusega, aga suurte puhul, nagu ka väga rikaste puhul, on vaja ka millestki mööda vaadata. Kas pole paratamatu, et madalad ja keskpärased natuurid just seetõttu, et nad kunagi ei riski ega pü̈udle kunagi tippudele, on enamasti veatud ja kindlas paigas, suurtele aga on suurus iseenesest riskiks. 3. Aga mulle pole teadmata ka teine asi, nimelt et kõiki inimlikke asju märgatakse alati halvema poole pealt ning et vigadest jä̈̈b kustutamatu mälestus, sellal kui kuni mälestus kaunist voolab kiirest minema. 4. Olen ka ise märganud päris arvukalt vigu Homerose ja teistegi puhul, kes on suurimad, ja kuigi need libastumised ei meeldi mulle sugugi, ei nimetaks ma neid siiski tahtlikeks vigadeks, vaid pigem hoolimatusest tulenevaiks tähelepanematusteks, mis tekivad üheskoos suure loomuse pidurdamatusega, kuidagi loomulikult ja nagu juhtub. Ning nendest hoolimata arvan ma, et suurimaid voorusi, isegi kui nad kõiges sellel tasemel ei ole, tuleb ikkagi alati esimeseks valida, kui mitte millegi muu, siis nende suursuguse loomu tõttu. Näiteks Apollonios on oma «Argonautikais» eksimatu looja, samuti nagu Theokritos on edukaim "Karjaselauludes", - välja arvatud mõned välised asjaolud - ent kas sooviksid olla Homeros või Apollonios? 5. Või mida arvad, kas Eratosthenes on "Erigones" (mis on igati laitmatu lühipoeem) suurem poeet kui Archilochos, kes sageli ohtralt ja kontrollimatult lainetab, ja tema jumaliku inspiratsiooni pursked, mida on raske reeglitele alluma panna? Kas sooviksid lü̈rikas olla pigem Bakchylides kui Pindaros ning tragöödias pigem Chiose Ion kui Sophokles? Sest esimesed on eksimatud ja kõigiti kaunilt lihvitud stiilis kirja pandud, Pindaros ja Sophokles ent otsekui leegitsevad kandudes, aga mõnikord kustuvad seletamatul kombel ning kukuvad onnetult. Ent ometi ei annaks ükski terve mõistusega inimene "Kuningas Oidipust" ära isegi terve Ioni loomingu eest.

34.1 Kui saavutusi hinnataks arvu, mitte suuruse järgi, siis oleks ka Hypereides igati üle Demosthenesest, kuna ta on kõlarikkam, tal on rohkem voorusi ja ta on peaagu kõiges tipu lähedal, just nagu viievõistleja, kes jääb igal jõukatsumisel alla teistele, esmaklassilistele võistlejatele, aga tuleb esimeseks tavakodanike seas. 2. Selle kõrval, et Hypereides jäljendab kõiki Demosthenese saavutusi peale kompositsiooni, valdab ta pealekauba ka Lysiase voorusi ja võlusid. Nimelt lobiseb ta lihtsalt seal, kus vaja, monotoonselt kõike üles lugemata, nagu öeldakse tegevat Demosthenes, ning iseloomustus on tal meeldivalt ja, Zeusi nimel, peenelt maitsestatud. Tal on ütlemata palju teravmeelsusi, linlik sarkasm, suursugusune päritolu, oskuslik irooniakasutus, vaimukad pilked, mis pole maitsetud, vaid Atika tervameelsuse laadis, mõnitamine on tal nutikas, torked väga naljakad ning naljad tabavad täpselt, - olles kõiges selles, võiks öelda, jäljendamatult köitev. Ta suudab loomupäraselt ülihästi haledust äratada, ladusalt jutustada, juttu nõtkelt ja inspireeritult edasi viia, olles ka äärmiselt mitmekülgne, nii et tema "Letost" on ülimalt poeetiline, "Matusekõne" on aga selline näidispala, millist minu teada mitte kellelgi teisel pole ette näidata. 3 Demosthenes aga ei loo karaktereid, pole kõneosav, ta pole ei inspireeritud ega etleja - talle pole omane midagi eelpool loetletust; kui ta pü̈̈̈ab vägisi naljakas või vaimukas olla, osutub ta pigem ise naeruväärseks teiste üle naermise asemel; kui ta pü̈̈ab läheneda köitvalt, siis kaugeneb ta täielikult. Kui ta oleks üritanud kirjutada Phryne või Athenogenese kohta pisikest kõnet, oleks see olnud veel enam soovituseks Hypereidesele. Ent ma arvan, et Hypereidese teosed on küll ilusad, aga samas ilma suurejoonelisuseta ning "kaine arvestusega südame tõttu tuimad" ning jätavad kuulaja liigutamata (näiteks Hypereidest lugedes ei hakka keegi kartma), Demosthenes aga võtab geniaalsena kõne üles täiuseni viidud vooruste, suursuguse hääle kõla, hingestatud tunnete, külluslikkuse, teravmeelsuse, väledusega - seal, kus see on kohane -, vägevuse ja võimususega, millele pole kellelgi ligilähedast ja ma väidan, et kui ta haarab endale kõik need jumalate poole saadetud vägevad kingid (sest poleks õige neid inimlikeks nimetada), siis selle kauni tõttu, mis tal on, saab ta alati kõigist võitu ja kompenseerib ka seda, mida tal pole ning otsekui kurdistab kõigi aegade kõnemehi oma kõuega ja pimes- 
tab välguga. Pigem suudaksid sa hoida silmad avali välgutabamuse ees, kui vastu astuda tema üksteisele järgevaile tundepurskeile.

35.1 Platoni väljapaistous, nagu ma ütlesin, on teistsugune. Lysias jääb temast kaugele maha nii vooruste suuruselt kui hulgalt, ning tema vigade arvukus kaalub üles ta vooruste puudujäägid. 2. Mida küll nägid need pooljumalad, kes kirjutamisel püüdlesid suurima poole ning põlgasid kõige puhul veatust? Lisaks paljule muule sedagi, et loodus ei ole meile, inimestele määranud madalat ega õilsusetut elukest, vaid on toonud meid ellu ja kogu maailma otsekui mingile suurele rõõmupeole, et saaksime vaatajaiks kõigele tema loodule ja ka auahneiks võistlejaiks; ta sisendas meie hingedesse võitmatu iha kõige selle järele, mis on alati suurejooneline ning meist jumalikum. 3. Seepärast ei piisa inimlike ettevõtmiste vaatlusele ja mõistmisele kogu kosmosestki, vaid meie mõtted ületavad sageli isegi seda ümbritsevad piirid. Ja kui keegi vaatleks elu ümbertringi, seda kuivõrd tähtsam on kõiges ülemõõduline, suur ja ilus, mõistaks ta kiiresti, milleks oleme sündinud. 4. Seetõttu tunneme me imetlust vastavalt loomusele. Zeusi nimel, me ei imetle väikesi ojasid, kuigi nad on selgeveelised ja kasulikud, vaid Niilust, Doonaud, Reini, ja üle kõige ookeani; ning kui oleme läitnud väikese tule, mille sära püsib muutumatuna, ei ole me rohkem hämmastuses kui taevaste tulede puhul, mis sageli tumenevad, ega pea seda imeväärsemaks Etna kraatrist, mis paiskab oma sügavusest üles kaljusid ja terveid kivikuhje ning saadab mõnikord välja maapõuest ja ainult sellest sündinud tule jõgesid. 5. Ent kõige sellise kohta võiksime öelda, et see, mis on kasulik ja ka paratamatu, on inimeste jaoks odav, sellal kui ebatavaline on alati imeväärne.

36.1 Loomupäraselt suurte sõnameistrite puhul, kelle suursugusus ei lähe välja vajalikkuse ja kasulikkuse piiridest, tuleb niisiis tähele panna, et kuigi sellised autorid on kaugel eksimatusest, on nad kõik sedavõrd kõrgemal lihtsurelikest. Kõige muu kasutamine tõendab, et nad on inimesed, ülevus aga tõstab nad jumala vaimusuuruseni. Ja kui eksimatust lihtsalt ei laideta, siis suurt koguni imetletakse. 2. Miks peaks veel lisaks rääkima, et igaüks sellistest meestest lunastab kõik oma vead sageli üheainsa ülevuse ja õnnestumisega, ning mis kõige tähtsam, kui koguksime kokku kõik Homerose, Demosthenese, Platoni ja teiste suurimate autorite eksimused, osutuks see väikseimaks, kordades tähtsusetuimaks osaks, võrreldes sellega, mis neil heerostel on igati õnnestunud. Seetõttu annavad kõik ajastud ja maailm neile võidupärja, mida ei saa ära võtta mingi hullunud kadedus, mida nad on hoidnud alal praeguseni ja küllap ka tulevikus:
Veel kuni voolamas veed ning kõrguvad puudegi kroonid [cf. Platon "Phaidros", 264c].

36.3 Sellele aga, kes kirjutas, et puudustega koloss ei ole parem kui Polykleitose Doryphoros („Odakandja“), saab lisaks paljule muule öelda et kunsti [technē] puhul imetletakse kõige suuremat täpsust, looduse teoste puhul aga suurust, kusjuures inimene on oma looduse järgi kõnevõimeline. Ja kui kujude puhul otsitakse sarnasust inimesega, siis kõne puhul seda mis ületaks, nagu ma ültlesin, inimliku. 4. Ometi (ja see soovitus pöördub tagasi käsitluse alguse juurde), kuna veatus on enamasti kunsti saavutus, suure loomupära oma aga see, mida on ülemääraselt (väja arvatud ühetabasus), siis on kohane, et kunst oleks alati loodusele abistajaks. Sest nende ühendusest võib igal pool sündida täiuslikkus.

Seda oli tarvis öelda meie ette pandud küsimuste kohta, aga igaüks tundku rõõmu sellest, mis talle naudingut pakub.

Janika Päll: Sea Motifs and the Image of the Sublime: Some Examples from Estonian Poetry and Art

KeyWords: Romantic sublime; GRAndeur; SEA; Estonian art; TRANSLATION

SUMMARY:

the article begins by explaining the background of sea motifs, which can be understood as sublime in the classical theory of arts, beginning with Pseudo-Longinus and continuing with Boileau and Burke, and the re-visitation of Aristotelian theory by the latter. This part of the article focuses on the observations of grandeur, dramatic change and danger in nature, which were defined as sublime in antiquity (based on examples from Homer and Genesis in Longinus or the Gigantomachy motifs in ancient art), as well as on the role of emotion (pathos) in the Sublime. The Renaissance and Early Modern Sublime reveal the continuation of these trends in Burke's theories and the landscape descriptions of Radcliffe in the Mysteries of Udolpho. In the latter, we also see a quotation from Beattie's Minstrel, whose motif of a sea-wrecked mariner represents the 
same type of sublime as Wordsworth's Peele Castle (which, in its turn, was inspired by a painting by Sir George Beaumont). This sublimity is felt by human beings before mortal danger and nature's untamed and excessive forces. In German poetry and art such sublimity can be seen in the works of Hölderlin or Caspar David Friedrich. However, $16^{\text {th }}$ and $17^{\text {th }}$ century poetry and painting rarely focused on such sublimity and preferred the more classical harmonia discors, in which ruins or the sea were just a slight accent underlining general harmony.

The article continues, focusing on the sea motifs in Estonian art and poetry. In Estonian art (initially created by Baltic Germans), the reflections of the magnificent Sublime in the paintings by August Matthias Hagen can be seen as the influence of Caspar David. In poetry, we see sublime grandeur in the ode called Singer by the first Estonian poet, Kristjan Jaak Peterson, who compared the might of the words of future Estonian poets to stormy torrents during a thunderstorm, in contrast to the Estonian poetry of his day, which he compared to a quiet stream under the moonlight. The grandeur, might and yearning for sublimity is reflected in the prose poem Sea (1905) by Friedebert Tuglas, who belonged to the Young Estonia movement.

This movement was more interested in modernity and city life than in romantically dangerous or idyllic landscapes. However, the main trends of Estonian poetry seem to dwell on idyllic landscapes and quietly sparkling seas, as for example, in a poem by Villem Ridala or sea landscape by Konrad Mägi. We also see this type of sublimity at the end of the $20^{\text {th }}$ and beginning of the $21^{\text {st }}$ centuries in the soundscapes of the sea by Ester Mägi or paintings by Aili Vint.

After World War II, the influence of the romantic ode genre and sublime can be seen in a translation of Byron's Stanzas for Music (1815) by Minni Nurme (1950). In Byron's gentle, sweet and serene picture of a lulled and charmed ocean, the underlying dimension of the divine, and the grandeur and power of the music is not expressed explicitly. Nurme tries to bring the translation into accord with the ode genre, thereby causing a shift from the serene to the grand sublime, by focusing on the depth of water and feelings, the greatness of the ocean, and most of all the rupture of the soul, which has been the most important factor in the sublime theory of Pseudo-Longinus. Her translation also seems influenced by her era of post-war Soviet Estonia (so that Byron's allusions to the divine word have been replaced by the might of nature). In the same period, Estonia's most vivid description of the romantic sublime appears in the choral poem Northern Coast (1958) composed by Gustav Ernesaks, with lyrics by another Estonian poet, Kersti Merilaas.

\begin{abstract}
Coastline in a leap,
on the spur of attacking;

each other tightly the sea

and the land here are holding

The rocky banks,

breast open to winds,

are hurling downwards

the pebbles and chunks.

Its adversary's waves

now grasp for its feet,

gnawing and biting

into the shores.
\end{abstract}

Stop now! No further from here,

neither of you can proceed any more!

Full of might is the sea,

more powerful is the land.

$\mathrm{CV}$ :

Janika Päll (b. 1965) has studied music and acquired a PhD in classical philology, as well as taught and studied the Ancient Greek and Latin languages and literature at the University of Tartu. She is presently working as a researcher at the University of Tartu Library focusing on Greek studies from the Renaissance and Humanist periods. 
